\title{
Production of monoclonal antibodies against Streptococcus mutans antigens
}

\section{Produção de anticorpos monoclonais contra antígenos de Streptococcus mutans}

\author{
Antonio Carlos Victor Canettieri* \\ Fujiko Yamasiro Kretchetoff** \\ Cristiane Yumi Koga Ito*** \\ Daniella Moreira* \\ Fabio José Condino Fujarra**** \\ Carmelinda Schmidt Unterkircher ${ }^{* * * *}$
}

\begin{abstract}
Several studies have been conducted in the last decades aiming to obtain an anti-caries vaccine, however some studies have demonstrated cross reactivity between Streptococcus mutans surface antigens and the human cardiac tissue. In this work, the reactivity of five anti-Streptococcus mutans monoclonal antibodies (MoAb) (24A, 56G, C8, E8 and F6) was tested against oral streptococci, cardiac antigens and skeletal and cardiac myosins, aiming to evaluate the specificity of these MoAb. The hybrid producers of immunoglobulins of the IgG $\mathrm{I}_{2 \mathrm{~b}}$ class were cloned by limit dilution and expanded in vivo. MoAb were tested by ELISA. The hybrid 24A reacted with $S$. mutans CCT 1910, S. salivarius CCT 0365 and S. pyogenes T23. No reactivity difference was observed among the tested species. Cross reactivity with heart and cardiac myosin was not confirmed and only reaction with myosin of skeletal muscle was observed $(\mathrm{p}=0.0381)$. The hybrid $56 \mathrm{G}$ reacted with all the tested microorganisms and there was statistically significant difference between S. mutans and S. pyogenes T23 (p < 0.001). This hybrid also reacted with myosin of skeletal muscle $(\mathrm{p}=0.0095) . \mathrm{C} 8, \mathrm{E} 8$ and F6 presented low reactivity against oral streptococci strains and no reactivity against cardiac antigens. The data of this study showed that the $24 \mathrm{~A}$ and $56 \mathrm{G}$ anti-S. mutans MoAb presented reactivity with $S$. pyogenes and $S$. salivarius, reinforcing the occurrence of common antigens between these species. The tested MoAb presented low cross-reactivity with myosin of skeletal muscle, but anti-heart activity could not be confirmed.
\end{abstract}

DESCRIPTORS: Antibodies, monoclonal; Streptococcus mutans.

RESUMO: Diversos estudos foram realizados nas últimas décadas com o intuito de se obter uma vacina anticárie dentária, mas alguns trabalhos têm demonstrado reatividade cruzada entre antígenos de superfície de Streptococcus mutans e tecido cardiaco humano. Neste trabalho, foi testada a reatividade de cinco anticorpos monoclonais (AcMo) anti-Streptococcus mutans (24A, 56G, C8, E8 e F6) contra estreptococos orais, antígenos cardíacos e miosinas esquelética e cardiaca, no intuito de avaliar a especificidade desses AcMo. Os híbridos produtores de imunoglobulinas da classe $\operatorname{IgG}_{2 \mathrm{~b}}$ foram clonados por diluição limite e expandidos in vivo. Os AcMo foram testados por ELISA. O híbrido 24A reagiu com S. mutans CCT 1910, S. salivarius CCT 0365 e S. pyogenes T23. Nenhuma diferença de reatividade foi detectada entre as espécies analisadas. Reatividade cruzada com coração e miosina cardíaca não foi confirmada, existindo somente reação com miosina de músculo esquelético $(p=0,0381)$. O híbrido $56 \mathrm{G}$ reagiu com todos os microrganismos testados e houve diferença estatisticamente significante entre $S$. mutans e S. pyogenes T23 ( $<<0,001)$. Este híbrido também reagiu com miosina de músculo esquelético $(p=0,0095)$. C8, E8 e F6 apresentaram baixa reatividade contra cepas de estreptococos orais e nenhuma reatividade com antigenos cardíacos. Os dados deste trabalho demonstraram que os AcMo 24A e 56G anti-S. mutans reagiram com S. pyogenes e S. salivarius, confirmando a existência de antígenos comuns entre essas espécies. Esses AcMo avaliados apresentaram baixa reatividade cruzada com miosina de músculo esquelético, porém a atividade anticoração não foi confirmada.

DESCRITORES: Anticorpos monoclonais; Streptococcus mutans.

\footnotetext{
* Graduate Students; ***Professor of Microbiology and Immunology; *****Professor - Department of Biosciences and Oral Diagnosis, School of Dentistry of São José dos Campos, São Paulo State University.

** Professor of Microbiology and Immunology, University of Mogi das Cruzes.

**** Graduate Student, Department of Neurology, University of São Paulo.
} 
Canettieri ACV, Kretchetoff FY, Ito CYK, Moreira D, Fujarra FJC, Unterkircher CS. Production of monoclonal antibodies against Streptococcus mutans antigens. Braz Oral Res 2006;20(4):297-302.

\section{INTRODUCTION}

S. mutans has been considered the main bacterial species involved in the etiology of dental caries. ${ }^{8}$ The main surface antigens are the enzymes glucosyltransferase (GTF) that converts sucrose, present in the human diet, into glucans (extracellular polysaccharides) that are responsible for $S$. mutans adherence to teeth. Another important proteinic antigen was denominated I/II, and it works as an adhesin, being important for the adherence mechanism of $S$. mutans to the receptors of salivary acquired pellicle. Immunizations with antigen I/II and glucosyltransferases protected experimental animals against dental caries. ${ }^{11,13}$ Researches in humans, using passive immunization with MoAb for antigen I/II (185 $\mathrm{kDa})$ showed that this procedure might hinder the early implantation of S. mutans, delaying the oral colonization by these microorganisms. ${ }^{12}$ Unfortunately, some studies demonstrated some degree of cross reactivity between $S$. mutans surface antigens and human cardiac tissues, making not viable a protocol of active immunization. ${ }^{15}$

The studies on S. mutans antigens and immunological responses to these components are important to comprehend the anti-dental caries defenses. Considering this, analysis of the specificity of monoclonal antibodies may help in the selection of interesting antigens for an anti-caries vaccine.

\section{MATERIAL AND METHODS \\ Production of anti-S. mutans monoclonal antibodies}

\section{Cell culture}

Cells of the lineage Sp2-Oag14 (myeloma cells) and the hybrids obtained were cultivated in RPMI1640 medium (Sigma, Baden-Wuttemberg, Steinheim, Germany) containing $1 \mathrm{mM}$ L-glutamine (Sigma, Baden-Wuttemberg, Steinheim, Germany), 10 mM Hepes (Sigma, Baden-Wuttemberg, Steinheim, Germany), 24 mM sodium bicarbonate (Sigma, BadenWuttemberg, Steinheim, Germany), $40 \mathrm{mg} / \mathrm{ml}$ gentamicin sulphate (Shering, Rio de Janeiro, Rio de Janeiro, Brazil) and supplemented with 10\% fetal bovine serum (Sigma, Baden-Wuttemberg, Steinheim, Germany). Both were maintained in humid atmosphere with $5 \% \mathrm{CO}_{2}$ and at $37^{\circ} \mathrm{C}$.

\section{Fusion protocol}

The protocol proposed by Goding 4 (1980), with modifications, was followed. Female Balb/c mice were immunized intradermically in the tail basis with $200 \mu \mathrm{g}$ of $S$. mutans cytoplasmatic antigen (CAg) in Freund's complete adjuvant, and then restimulated by intraperitoneal via after 21 days with the same antigen in saline solution buffered with phosphate (PBS - Sigma, Missouri, St. Louis, USA). Three days after the booster, the animals were sacrificed and had their spleen removed. This organ was macerated and its cells $\left(10^{8}\right)$ were fused with the lineage Sp2-Oag14 $\left(5 \times 10^{7}\right)$, using $45 \%$ polyethyleneglycol (PEG) (Sigma, Baden-Wuttemberg, Steinheim, Germany) as a fusion agent and $10 \mathrm{ml}$ of RPMI. Then, the suspension was agitated for 10 minutes. Polyethyleneglycol was eliminated by centrifugation and the cells were resuspended in RPMI medium supplemented with hypoxanthine, aminopterin and $20 \%$ thymidine (HAT) (Sigma, Baden-Wuttemberg, Steinheim, Germany). Hybrids were distributed at a $1 \times 10^{6}$ ratio on the feeder layer, prepared the previous day with the spleen of a non-immunized animal $\left(1.6 \times 10^{5}\right)$, feeding them each 5 days. After seven days, the cell culture was examined with the aid of an inverted microscope (Nikon, model 104; Melville, New York, USA). After 10 days, the HAT medium was replaced by $20 \%$ HT (hypoxanthine and aminopterin) (Sigma, Baden-Wuttemberg, Steinheim, Germany), and after 12 days the points presenting confluent growth were tested by the ELISA technique for the antigen used in the immunization. The positive points were cloned in the common ratio of $1 / 2$ and the hybrids of interest were expanded in vitro and in vivo in Balb/c mice.

\section{Antigen obtaining}

\section{S. mutans cytoplasmatic antigens preparation}

S. mutans CCT 1910 was grown in triptic soy broth (TSB, Difco, Detroit, USA) at $37^{\circ} \mathrm{C}$ for 24 hours with $5 \% \mathrm{CO}_{2}$, killed by $0.075 \%$ formaldehyde and then maintained for 18 hours at $4^{\circ} \mathrm{C}$. The suspension was centrifuged and the cells were washed in $125 \mathrm{mM}$ 2,3 dibromopropyl-chlorydric acid (Tris-HCl; Life Technologies, New York, USA) $\mathrm{pH}$ 7.5, $10 \mathrm{mM}$ EDTA, and resuspended in $50 \mathrm{ml}$ of the same buffer. After that, $5 \mathrm{mM}$ phenylmethyl sulphonyl fluoride (PMSF, Sigma, Steinheim, Germany) was added and the suspension was agitated vigorously with glass beads overnight at $4^{\circ} \mathrm{C}$. The lisate was centrifuged and the supernatant was dialysed against distilled water, concentrated and liophylized, constituting the cytoplasmatic antigen (CAg). The proteinic content was determined by the Bradford $^{2}$ (1976) method. 
Canettieri ACV, Kretchetoff FY, Ito CYK, Moreira D, Fujarra FJC, Unterkircher CS. Production of monoclonal antibodies against Streptococcus mutans antigens. Braz Oral Res 2006;20(4):297-302.

\section{Streptococci whole cells preparation}

S. mutans (CCT 1910) cells, S. salivarius (CCT 0365) and S. pyogenes (CCT 1500 and T23) were grown in triptic soy broth (TSB, Difco, Detroit, USA) for 24 hours and killed by $0.075 \%$ formaldehyde. After a wash step in PBS and 10,000 g centrifugation at $25^{\circ} \mathrm{C}$ for $20 \mathrm{~min}$, the suspensions were standardized by spectrophotometry $(595 \mathrm{~nm}$ and optical density of 0.200 ).

\section{Self-antigen preparation}

Myosin from pig cardiac muscle (Sigma, BadenWuttemberg, Steinheim, Germany) and from mice skeletal muscle ( $6 \mathrm{mg} / \mathrm{ml})$, kindly donated by Dr. Ternynck (Pasteur Institute, Paris), were included in the study.

\section{Heart extract preparation}

Twenty Balb/c mice were sacrificed and had their hearts removed. They were washed in PBS, macerated and filtered in sterile gauze. The filtrate was maintained at $-20^{\circ} \mathrm{C}$. The pellet was transferred to $5 \mathrm{ml}$ of a buffer solution containing $150 \mathrm{mM}$ Tris-HCl, $6 \mathrm{M}$ urea, $20 \mathrm{mM}$ 2-mercaptoethanol and 1\% Tween 20 (Merck, Hessen, Darmstadt, Germany). The mixture was boiled for five minutes and then maintained under refrigeration for 24 hours. It was then centrifuged and the supernatant was dialysed against PBS overnight. Both were concentrated by ultra-filtration. The proteinic concentration was estimated in $30 \mu \mathrm{g} / \mu \mathrm{l}$ by the Bradford² (1976) method.

\section{ELISA technique}

Polystyrene plates (number 3590, Costar, Cambridge, MA, USA) were coated with whole streptococci cells, with myosin $(5 \mu \mathrm{g} / \mathrm{ml})$ and heart extract $(10 \mu \mathrm{g} / \mathrm{ml})$ in $0.1 \mathrm{M}$ carbonate buffer (pH 9.6) and incubated for 2 hours at $37^{\circ} \mathrm{C}$ and for 18 hours at $4^{\circ} \mathrm{C}$. The wells were blocked with $0.5 \%$ gelatin (Merck, Hessen, Darmstadt, Germany) in phosphate buffered saline (PBS-G) for 30 minutes at $37^{\circ} \mathrm{C}$. Then the plates were washed with $0.5 \%$ Tween 20 PBS (T-PBS). The supernatants of the culture and/or ascites diluted in T-PBS-G were added to the wells, in duplicate, and diluted in the common ratio of $1 / 2$. Plates were incubated for 2 hours at $37^{\circ} \mathrm{C}$, and maintained at $4^{\circ} \mathrm{C}$ overnight. After an additional wash step with T-PBS, $50 \mu \mathrm{l}$ of anti-mice IgG peroxidase-labelled (Sigma, BadenWuttemberg, Steinheim, Germany) were added to the wells $(1 \mu \mathrm{g} / \mathrm{ml})$ and incubated for 1 hour at $37^{\circ} \mathrm{C}$. Finally, $100 \mu 1 /$ well of $o$-phenylenediamine (Merck, Hessen, Darmstadt, Germany) in $0.1 \mathrm{M}$ citrate buffer (pH 5.5) (Merck, Hessen, Darmstadt, Germany) were added at room temperature until a yellow color developed. The reaction was stopped with 2.5 M sulfuric acid (Merck, Hessen, Darmstadt, Germany) and the color was measured at $490 \mathrm{~nm}$ with a model 3550 reader (Bio Rad Laboratories, California, Hercules, USA). Three experiments, in duplicate, with their respective controls (Irrelevant MoAb 17C) were performed. The concentration of $5 \mu \mathrm{g} / \mathrm{ml}$ was elected for statistical analysis, as this value was the mean point of the curves.

\section{Statistical analysis}

The data obtained were analyzed by MannWhitney and Kruskal-Wallis tests, at the level of significance of $5 \%$.

\section{RESULTS}

\section{MoAb production by hybrids}

All the points with optical densities obtained by ELISA higher than 0.300 were considered positive. This value corresponds to at least three times the mean reactivity of a control serum of mice diluted at 1:100.

\section{First fusion}

Twenty-seven hybrids (4.6\% of the plated points) presented confluent growth in six plates of 96 wells (576 points) in the first reading, and three points $(11.1 \%)$ were positive for S. mutans in ELISA. Among these hybrids, only two continued to produce IgG antibodies after initial cloning and were recloned by limit dilution. The hybrids that produced antibodies were denominated $24 \mathrm{~A}$ and $56 \mathrm{G}$.

\section{Second fusion}

Sixty-six hybrids $(11.4 \%$ of the total of plated points) were obtained, seventeen produced antibodies against $S$. mutans and only three $(4.5 \%)$ maintained the production of IgG (C8, E8 and F6).

\section{Reactivity of MoAb in ELISA}

C8, E8 and F6 presented low reactivity against oral streptococci strains (data not shown). Only the antibodies produced by $56 \mathrm{G}$ and $24 \mathrm{~A}$ showed reactivity against heart antigens, skeletal and car- 
Canettieri ACV, Kretchetoff FY, Ito CYK, Moreira D, Fujarra FJC, Unterkircher CS. Production of monoclonal antibodies against Streptococcus mutans antigens. Braz Oral Res 2006;20(4):297-302.

diac myosins. Graphs 1 and 2 show the reactivity of MoAb 24A and 56G to the different species of streptococci and to the auto-antigens.

Graph 1 shows that the reactivity levels of MoAb 24 A to S. mutans, S. salivarius and S. pyogenes T23 were significantly higher when compared to that of the irrelevant MoAb 17C ( $p=0.0190$, $p=0.0095, p=0.0095$, respectively), but no significant difference was found for $S$. pyogenes CCT $1500(\mathrm{p}=0.9143)$. No differences in the reactivity of MoAb 24A to the different species of streptococci were found. Regarding the reactivity of $56 \mathrm{G}$, significant levels were observed against all the tested species ( $p=0.0095$ in all cases). The values were compared to verify if the antibody might discriminate $S$. mutans among the tested species, and statistically significant difference was observed only between $S$. mutans and $S$. pyogenes T23 $(\mathrm{p}<0.001)$.

Regarding cross reactivity, Graph 2 shows that the level of significance in the case of MoAb $24 \mathrm{~A}$ was reached only with skeletal muscle myosin $(\mathrm{p}=0.0381)$. Considering the heart antigen and cardiac myosin, the reactivity of MoAb $24 \mathrm{~A}$ was not statistically significant. The most marked mean reactivity for the heart did not present statistical significance; however, an elevated standard deviation was observed due to the great variability among the results of the analysed strains. It could be observed that MoAb $56 \mathrm{G}$ also reacted significantly with skeletal muscle myosin $(\mathrm{p}=0.0095)$, even though not mark-

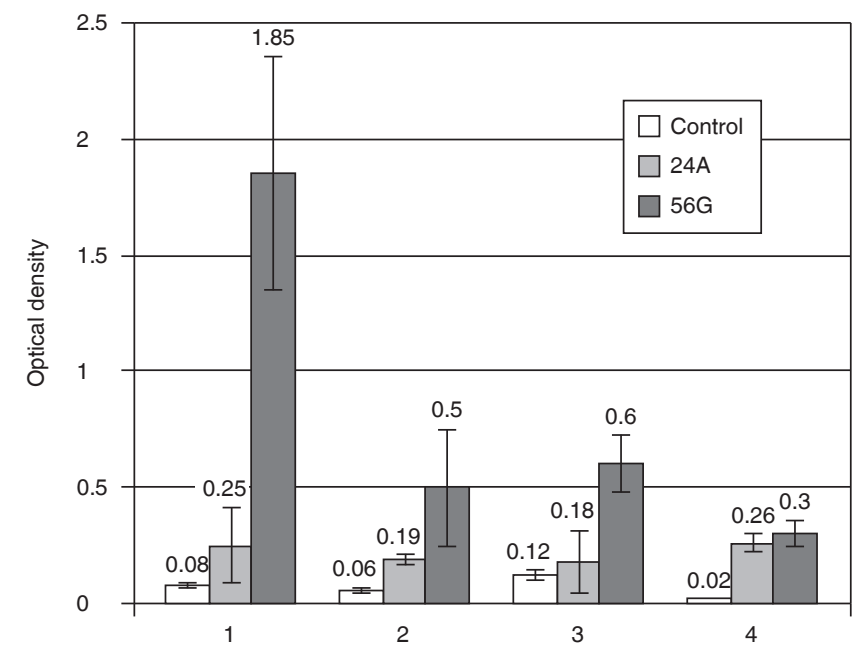

GRAPH 1 - Reactivity of the monoclonal antibodies against: 1) S. mutans CCT 1910; 2) S. salivarius CCT 0365 ; 3) S. pyogenes CCT 1500; 4) S. pyogenes T23. (Control: irrelevant MoAb 17C). edly. The values obtained for the reactions with heart and cardiac myosin were not statistically significant.

\section{DISCUSSION}

The MoAb obtained (56G, 24A, C8, E8 and F6) presented reactivity in ELISA with whole cells of three species of streptococci (S. mutans, S. salivarius and $S$. pyogenes). These results are in accordance with those of the study of Krisher, Cunningham $^{9}$ (1985) that produced a MoAb for $S$. pyogenes with cross reactivity to $S$. mutans and myosin of skeletal muscle. Adsorption of the ascite with M protein of S. pyogenes resulted in loss of this cross reactivity. The same occurred when the antibody was adsorbed with $S$. mutans, indicating the existence of homologous epitopes between these species.

MoAb 56G and 24A exhibited another particularity when compared with $\mathrm{C} 8, \mathrm{E} 8$ and F6. Both were reactive, even with low intensity, with self-components. In previous studies we demonstrated that mice immunized with CAg of $S$. mutans synthesized antibodies that were reactive to myosin of skeletal and cardiac muscles. ${ }^{10}$ van de Rijn et al. ${ }^{15}$ (1976) also noticed this phenomenon in rabbits immunized with antigens from several $S$. mutans strains that produced polyclonal antibodies that presented cross

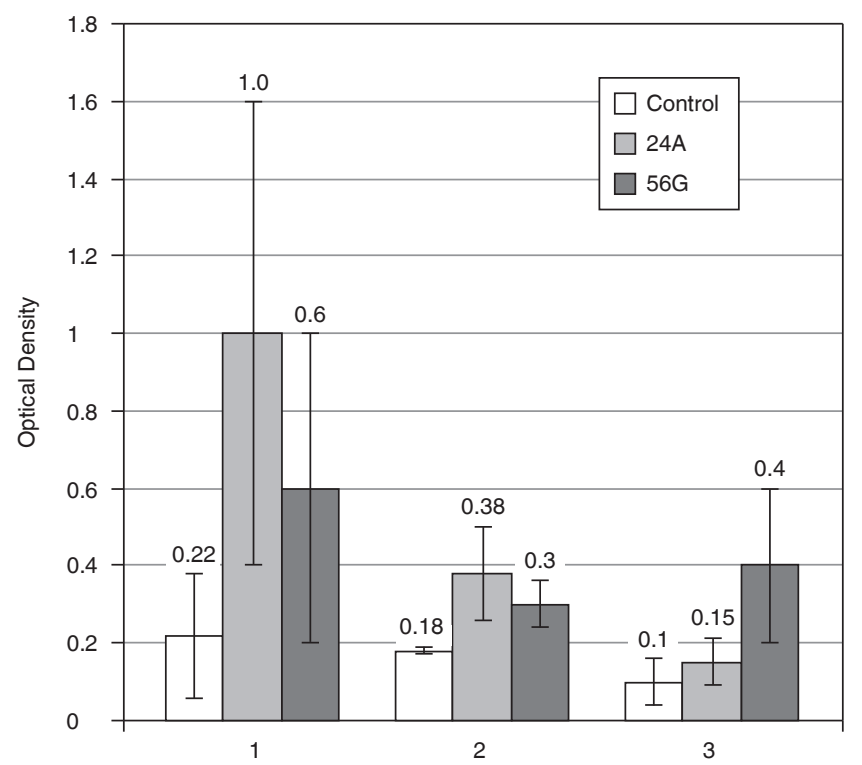

GRAPH 2 - Reactivity of monoclonal antibodies against: 1) Heart $(100 \mu \mathrm{g} / \mathrm{ml})$; 2) skeletal muscle myosin $(5 \mu \mathrm{g} /$ $\mathrm{ml})$; 3) cardiac myosin $(5 \mu \mathrm{g} / \mathrm{ml})$. (Control: Irrelevant MoAb 17C). 
Canettieri ACV, Kretchetoff FY, Ito CYK, Moreira D, Fujarra FJC, Unterkircher CS. Production of monoclonal antibodies against Streptococcus mutans antigens. Braz Oral Res 2006;20(4):297-302.

reactivity with cardiac tissue and skeletal muscle. Also, they observed that the adsorption of rabbit serum with sarcolemma extracts, S. mutans and A group $\beta$-haemolyticus streptococci removed completely the reactivity with mammalian tissues.

Since then, several studies demonstrated in a convincing way that antibodies with cross reactivity were present in the sera of immunized animals and in supernatants of unique clones, in the case of hybridomas, always associated to immunization with streptococci and infection by these microorganisms. . $^{3,13,14}$ In all the studies found in literature, the possibility that these reactions may be induced by rheumatoid factors (anti-immunoglobulin antibodies) was questioned. In fact, in the first attempts of hybridisation, ten antibodies reactive to streptococci were obtained. However, in all these cases no reactivity was detected by Western Blot. At least half of these antibodies presented activity of rheumatoid factor (data not shown). Russel ${ }^{13}$ (1987), after hiperimmunization of rabbits with whole cells of $S$. mutans, S. sobrinus, S. rattus and S. mitis, observed that the cross reactivity of serum auto-antibodies was not always associated to antigen I/II, the main S. mutans surface antigen. This author concluded, with the aid of a combined ELISA technique and gel diffusion, that the antibodies reactive to cardiac tissue did not bind to antigen I/II. Then, there were clearly two distinct populations of antibodies with different specificities. The author also observed an elevated level of IgM rheumatoid factor that might be responsible for the reactivity to cardiac tissue observed in previous studies.

In our results, anti-heart reactivity of the tested MoAb could not be confirmed by the statistical tests. The reactivity of these antibodies were of low intensity (as in 24A) or highly specific for S. mutans (56G). Also, both of them were IgG $_{2 b}$ isotypes. This result was expected as Leão et al. ${ }^{10}$ (2000) previously demonstrated an increase of this subclass and also of $\operatorname{IgG}_{2 \mathrm{a}}$ after immunization of mice with S. mutans cytoplasmatic antigen.

\section{REFERENCES}

1. Avrameas S, Ternynck T. Natural autoantibodies: the other side of the immune system. Res Immunol. 1995;146(4): 235-48.

2. Bradford M. A rapid and sensitive method for quantification of microgram quantities of protein utilizing the principle of protein-dye binding. Anal Biochem. 1976;7(72):248-54.

3. Ferreti JJ, Shea C, Humprey MW. Cross-reactivity of Streptococcus mutans antigens and human heart tissue. Infect Immun. 1980;30(1):69-73.
The data of this study did not exclude totally the reactivity to self-components. As evidenced by ELISA, 24A and 56G presented some degree of reactivity to skeletal muscle myosin. However, it is important to clarify that this reactivity was not intense, and that no experiment of adsorption was performed with the aim of eliminating it. And the hypothesis of reactivity induced by natural autoantibodies described by other researches for explaining the reaction between polyclonal antibodies and host tissues may not be discharged. These antibodies have been related to the pathogenesis of auto-immune diseases. ${ }^{1,6}$

Common antigens occur frequently in a bacterial genus, making it difficut to find species-specific monoclonal antibodies. The reactivity between $S$. mutans and S. pyogenes has been related in the literature and is considered by some authors as an additional factor in the development of rheumatic fever. $S$. mutans and S. pyogenes present similar antigens in the cell surface, and $S$. mutans may reach the blood circulation after dental procedures. This relation may constitute a constant antigenic stimulation in the development of rheumatic fever. ${ }^{5}$ This sharing of antigens between both species was reinforced in this study, considering that MoAb against S. mutans recognized superficial epitopes in $S$. pyogenes.

The monoclonal antibodies 24A and 56G isolated in this study (specially the 56G) will be valuable in future experiments, mainly in the fields of epidemiology and diagnosis of caries risk in children.

\section{CONCLUSIONS}

The isolated MoAb reacted in ELISA with whole cells of S. mutans. C8, E8 and F6 presented low reactivity against oral streptococci strains and no reactivity with self-components. The MoAb anti-S. mutans 56G and 24A recognized S. pyogenes and S. salivarius. Although anti-heart reactivity of MoAb $56 \mathrm{G}$ and 24A was not observed, there was reactivity with self-components (myosin of skeletal muscle).

4. Goding JW. Antibody production by hibridomas. J Immunol Methods. 1980;39(4):285-308.

5. Hirota K, Kanitani H, Nemoto K, Ono T, Miyake Y. Cross-reactivity between human sialyl Lewis(x) oligosaccharide and common causative oral bacteria of infective endocarditis. FEMS Immunol Med Microbiol. 1995;12(2):159-64.

6. Hughes EJ, Eichbaum Q, Beatty DW. Human monoclonal antibodies: analysis of two antibodies derived from lymphocytes of a patient with acute rheumatic fever. Med Lab Sci. 1991;48(4):244-55. 
Canettieri ACV, Kretchetoff FY, Ito CYK, Moreira D, Fujarra FJC, Unterkircher CS. Production of monoclonal antibodies against Streptococcus mutans antigens. Braz Oral Res 2006;20(4):297-302.

7. Hughes M. Evidence for an immunological relationship between Streptococcus mutans and human cardiac tissue. Infect Immun. 1980;27(2):576-88.

8. Jorge AOC. Microbiologia bucal. São Paulo: Santos; 1998.

9. Krisher K, Cunningham MW. Myosin: a link between streptococci and heart. Science. 1985;227(4685):413-5.

10. Leão MVP, Brandão AAh, Moraes E, Shimizu MT, Unterkircher CS. Detecção de anticorpo anticoração em camundongos Balb/c imunizados com Streptococcus mutans. Pesqui Odontol Bras. 2000;14(4):319-26.

11. Lehner T. Imunologia das doenças da boca. $3^{a}$ ed. São Paulo: Santos; 1996.
12. Ma JKC, Hunjan M, Smith R, Lehner T. Specificity of monoclonal antibodies in local passive immunization against Streptococcus mutans. Clin Exp Immunol. 1989;77(3):331-7.

13. Russel MW. Analysis of heart-reactive antibodies induced in rabbits by immunization with Streptococcus mutans. J Oral Pathol. 1987;16(4):234-40.

14. Stinson MW. Serology and tissue lesions in rabbits immunized with Streptococcus mutans. J Immunol. 1983;131(6):3021-7.

15. van de Rijn I, Bleiweis AS, Zabriskie JB. Antigens in Streptococcus mutans cross reactive with human heart muscle. J Dent Res. 1976;55:59-64.

Received for publication on Oct 31, 2005

Sent for alterations on May 03, 2006

Accepted for publication on Aug 03, 2006 